\title{
レーザ回折・散乱法における青紫色レーザの応用
}

\section{Application of Violet Laser to Laser Diffraction and Scattering Method}

\author{
木下 健 \\ Takeshi Kinoshita
}

Received 21 September 2001 ; Accepted 9 January 2002

Development of a new laser diffraction particle size distribution analyzer is discussed. One new feature is the laser source and the other is the light detection system. The laser employed is a short wave length violet laser, which improves the measuring ability down to ultra-fine particle region. The detection system adopting wide bore lens increases the measuring accuracy in fine particle range. The combination of the violet laser and the detection system makes the measuring range of the laser diffraction particle size analyzer wider.

Keywords : Particle size distribution, Particle size measurement, Laser diffraction method, Violet laser

\section{1. 緒言}

レーザ回折・散乱法を原理とする粒子径分布測定装 置において，測定下限粒子径を決定する主たる要因の 一つとして，使用レーザ光源の波長がある。より微細 な粒子を測定しょうとすれば，より短波長の光源を採 用する方が有利となる。従来のレーザ回折・散乱法を 原理とする粒子径分布測定装置では，光源として，波 長 $630 \mathrm{~nm} \sim 780 \mathrm{~nm}$ の赤色レーザが採用されていたた め, 測定下限粒子径は $0.02 \sim 0.1 \mu \mathrm{m}$ であった。測定 装置メ一カや機種により測定下限に差が生ずるのは, 散乱光をどの程度の角度まで測定しているか，といっ たことによる。

著者らは, $0.1 \mu \mathrm{m}$ より小さい超微粒子領域での粒 子径検出性能向上を目指し, 光源として $405 \mathrm{~nm}$ とい う短波長半導体レーザを，さらに前方から後方まで広 角度で散乱光を検出できる検出システムを検討してき た。その結果，これら新機軸を採用することにより， 超微粒子領域の測定性能を従来装置に比へ大幅に向上 させることができた。

本報では, 赤色レーザ光源を採用した従来方式と青

第 38 回粉体に関する討論会（2000年10月, 富山）にて発表 （株）島津製作所

（テ604-8511 京都市中京区西ノ京桑原町 1) TEL 075-823-1094

Shimadzu Corporation

(1. Nishinokyo-kuwabaracho, Nakagyo-ku, Kyoto 604-8511)
紫色レーザ光源を採用した新方式との光学系の違いを 述べると共に，それぞれの方式で測定される散乱光強 度分布パターンの違いをシミュレーション, および寒 試料の測定結果によって明確にし, 微粒子領域での測 定における青紫色レーザ光源の優位性を示したい。

\section{2. 理論的背景と装置構造}

レーザ回折・散乱法の基礎理論である Mie の散乱 理論においては，単一粒子に光を照射した場合の散乱 光強度分布は, Eq. (1)によって定義される粒子径パ ラメータ $\alpha$ にっって決定される1,2)。

$$
\alpha=\frac{\pi D}{\lambda}
$$

ここに, $D$ は粒子径（直径）， $\lambda$ は光の波長， $\pi$ は円 周率である。Eq. (1) によれば，ある粒子径と波長の 組み合わせに対して，例えば粒子径と波長が共に 2 分 の 1 になった場合を考えると，その前後で散乱光強度 分布はまったく变化しないことがわかる。

Fig. 1 は波長 405nm の青紫色レーザ光と波長 680 $\mathrm{nm}$ の赤色レーザ光を, 粒子径 $1.0 \mu \mathrm{m}$ から $0.1 \mu \mathrm{m}$ の 単独粒子に照射したときの散乱光強度分布を Mie の 散乱理論式1. 2)によって計算した結果である。それぞ れの図の中心に粒子が置かれており，左方から横軸に 沿ってレーザ光が照射されている。中心（粒子位置） からそれぞれのパターンの縁までの距離が，その方向 


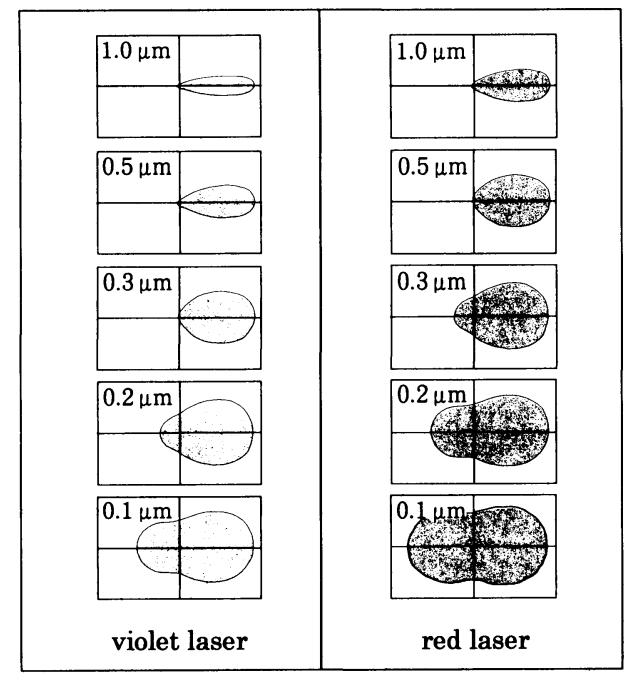

Fig. 1 The scattered light intensity distribution of violet laser and red laser by small particle

Side and back-

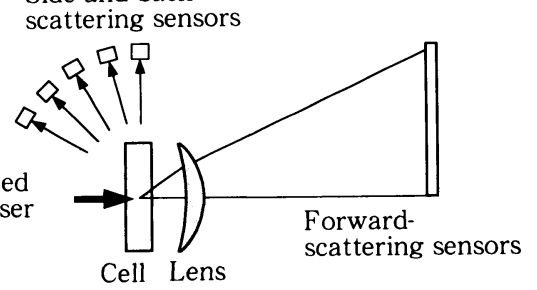

Fig. 2 Optical system of present instrument

での散乱光強度を示している。

二つの光源波長の比は $405 \mathrm{~nm} / 680 \mathrm{~nm} \fallingdotseq 0.6$ であ

り, 約 1 対 2 と見れば，例えば青紫色レーザ光による $0.1 \mu \mathrm{m}$ のパターンと赤色レーザ光の $0.2 \mu \mathrm{m}$ のパター ンは非常に似通ったものになるはずである。実際,

Fig. 1 の計算結果はそれを表している。レーザ回折・ 散乱法はこのパターンの違いによって粒子径を識別す る方法であるので, 粒子が微細になっていき, 粒子径 の違いによる散乱光強度パターンの違いが無くなる粒 子径領域 (Rayleigh 散乱領域)になると, そこが原理 上の測定下限ということになる。したがって, 微粒子 側での散乱強度パターンの差が出やすい波長の短い光 を使用すれば，原理上は微粒子側の測定下限を伸ばす ことができる。

Fig. 2 には赤色レーザ光源を使用した従来の装置の 光学系を，Fig. 3 には青紫色レーザ光源を使用した新 しい装置の光学系を示す。

著者らの新しい装置では, 青紫色レーザ光源の採用
Side and back-

scattering sensors

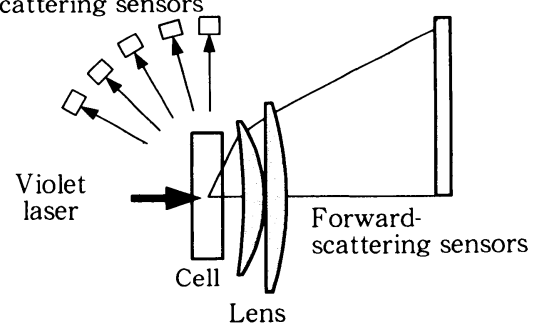

Fig. 3 Optical system of new instrument

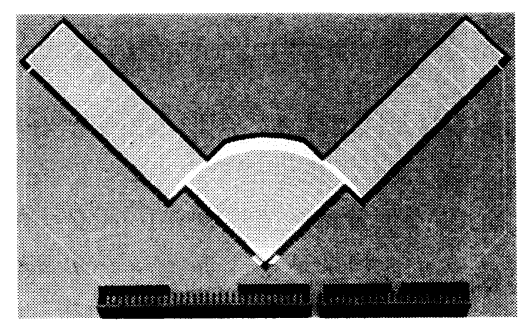

Fig. 4 Wing sensor

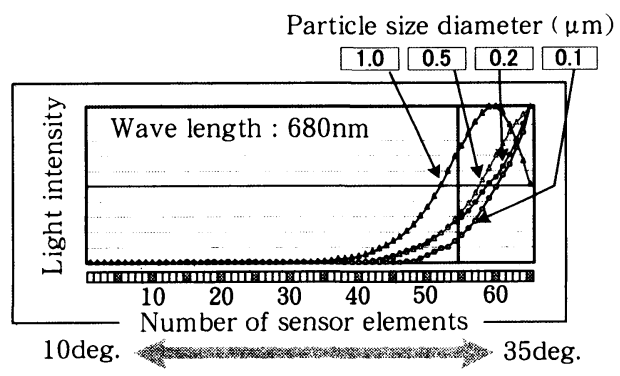

Fig. 5 The light intensity distribution by present instrument

Particle size diameter $(\mu \mathrm{m})$

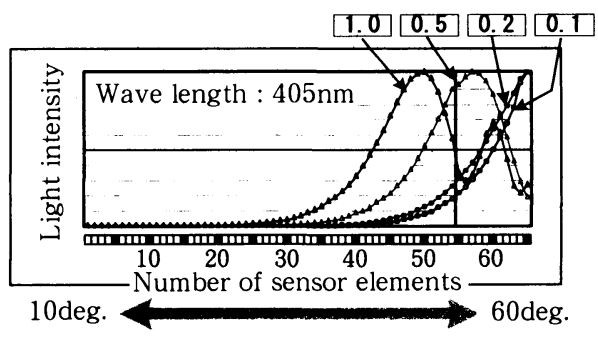

Fig. 6 The light intensity distribution by new instrument

に加えて, 従来と同じ形状, 同じ寸法の変形同心円七 ンサを使用しつつも，より広角度の散乱光まで捉える ことができるように大口径レンズを使用することにし た。この方法により, 微粒子頱域の測定精度向上が可 能となった。Fig. 4 は, 変形同心円センサをレーザ光 
Table 1 The samples used for experiment

\begin{tabular}{|c|c|c|c|}
\hline Name of samples & particle size & $\mathrm{CV}$ & Distributer \\
\hline \multirow{5}{*}{ Spherical polystyrene latex } & $34 \mathrm{~nm}$ & $\mathrm{n} / \mathrm{a}$ & \multirow{5}{*}{ Duke scientific co. ltd. } \\
\hline & $50 \mathrm{~nm}$ & $13.4 \%$ & \\
\hline & $300 \mathrm{~nm}$ & $1.4 \%$ & \\
\hline & $802 \mathrm{~nm}$ & $1.2 \%$ & \\
\hline & $2.013 \mu \mathrm{m}$ & $1.1 \%$ & \\
\hline \multirow{3}{*}{ Spherical silica particle } & $19-30 \mathrm{~nm}$ & - & \multirow{3}{*}{$\begin{array}{l}\text { Catalysts \& chemical } \\
\text { ind. co., ltd. }\end{array}$} \\
\hline & $35-55 n m$ & - & \\
\hline & $70-90 \mathrm{~nm}$ & - & \\
\hline
\end{tabular}

照射方向から見た図である。扇形と短冊型の白い部分 は絶縁部，黒い部分が感知部である。

Fig. 5 および Fig. 6 は，公称值 $0.1 ， 0.2 ， 0.5 ， 1.0$ $\mu \mathrm{m}$ のラテックス標準球を, 赤色レーザ（波長 680 $\mathrm{nm}$ ）を採用した従来装置と, 青紫色レーザ（波長 $405 \mathrm{~nm}$ ）を採用した新型装置で測定したときの前方散 乱光強度分布である。

Fig. 5, Fig. 6 の縦軸は光強度, 横軸は Fig. 4 の センサの扇形感知部の中心から短冊状の外側へ向か って与えた番号を示してある。すなわち, 横軸を右 に行くほど高角度での散乱光ということになる。ま た, Fig. 1 に示した散乱光強度分布は点強度の分布 であったが, Fig. 5 およびFig. 6 の強度分布は，そ れを各センサ素子の面上で積分したものになるため,

Fig. 1 の分布とは異なったものになっている。さら に, 光強度分布のピーク（極大点）位置が図上で右 （高角度）に行くほど, 粒子径は小さいということに なる。Fig. 5 およびFig. 6 からわかるように，赤色 レーザを採用した従来装置では， $1.0 \mu \mathrm{m}$ のパターン に極大点が存在しているが, $0.5 \mu \mathrm{m}$ のパターンには 存在していない。言い換えると, 変形同心円センサの 65 番目の素子上，または，それょりも外側に極大点 があるということになる。これに対し，青紫色レーザ を採用した新型装置では $0.5 \mu \mathrm{m}$ のパターンにも極大 点が存在している。青紫色レーザの波長が赤色レーザ の 6 割程度に短いことに加えて, 受光部で捉えられる 角度範囲が広くなったことにより，前方散乱光センサ (変形同心円センサ) だけでカバーする測定範囲が微 粒子側に大きく広がっていることがわかる。

\section{3. 実験方法}

青紫色レーザを使用した新しい装置の測定下限値と 微粒子領域での分解能を, いくつかの試料を測定する

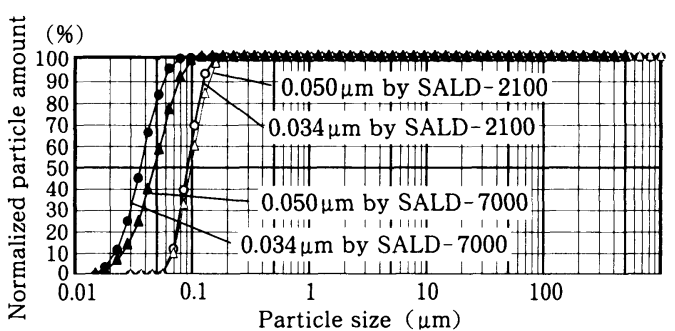

Fig. 7 Particle size distribution of polystyrene latex measured by SALD -2100 and SALD -7000

\section{ことにより検討した。}

本研究においては，青紫色レーザ光源を含めた新型 光学系を採用した実験用測定装置として，（株）島津 製作所製レーザ回折式粒度分布測定装置 SALD 7000 を用いた。また, 比較対象用の赤色レーザ光源 を採用した従来装置として, 同社 SALD- 2100 を用 いた。

実験用の試料を Table 1 に示す。

\section{4. 実験結果と考察}

\section{1 ラテックス標準球 2 種}

公称値 $34 \mathrm{~nm}$ と $50 \mathrm{~nm}$ のポリスチレンラテックス 標準球を，SALD-7000 とSALD-2100 で測定した。 その結果を Fig. 7 に示す。

SALD- 2100 では，この 2 種の粒子は共に，90nm から $100 \mathrm{~nm}$ の中心径の粒子として計測されており, 公称値から大きくずれると共に 2 試料間の差も小さ い。これに対し SALD-7000では，その中心粒子径 は公称值に近く，かつ，2試料の識別も十分できてい る。

ところでここに使用したポリスチレンラテックス 標準球は，ほぼ完全な単分散粒子といってよいもの 


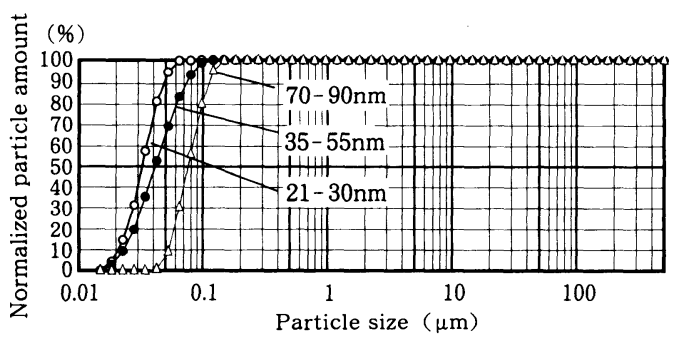

Fig. 8 Particle size distribution of spherical silica particles measured by SALD-7000

で，本報における測定結果にあるような粒子径分布を 持つものではない。しかしながら，明確な粒子径分 布，もしくは粒子径を持った試料がなかなか準備しづ らいという現状から，粒子径分布測定装置の性能確認 という目的に比較的よく使用される。本報で示したよ うな分布を持つ測定結果は箃密な意味では誤りという ことになるが, レーザ回折・散乱法という測定法の原 理的な限界を踏まえた上で, 粒子径の識別能力を確認 するという目的には，十分に使用可能な試料であり， その測定結果にも一定の意味はある。

\section{2 球状シリカ微粒子 3 種}

公称値 20-30nm, 35-55nm, 70-90nm の球状シ リカ微粒子を SALD- 7000 で測定した。その結果を Fig. 8 に示す。

70-90nm と 35-55nm の試料が公称值にかなり近 いのに対し， 20-30nm の試料の測定結果はやや大き めにシフトしている。この測定結果から，この装置の 中心径の測定下限値が $30 \mathrm{~nm}$ 強のところにあること が実験結果からわかる。

Fig. 9 は, Fig. 8 の粒子径分布の生データとも言う べき光強度分布である。比較を容易にするため最大強 度（いずれの試料も 90 度方向の散乱光）で規格化し ている。三つの試料の光強度分布, 主として散乱角度 で 60 度以下の領域（センサ素子番号では 65 番以下の 領域）には明らかに違いが見られ，試料間の差異をよ く検出していることがわかる。この結果から，20-30 $\mathrm{nm}, 35-55 \mathrm{~nm}, 70-90 \mathrm{~nm}$ の 3 種の試料は, 光強度 分布のレベルで識別がなされており，単に数学的な処 理の結果として粒子径分布の差が出てきているのでは ないことがわかる。

4. 2 項のポリスチレンラテックス標準球と合わせて 考えると，SALD-2100 の中心径としての測定下限 值は 90nm 前後にあり, SALD-7000 の測定下限值 は $30 \mathrm{~nm}$ 強のところにあることがわかる。 SALD7000 のレーザ光源波長は SALD- 2100 の約 6 割程度

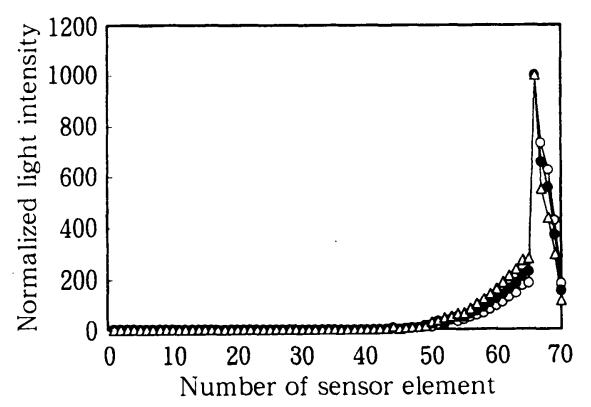

Fig. 9 Normalized light intensity distribution of spherical silica particles measured by SALD -7000

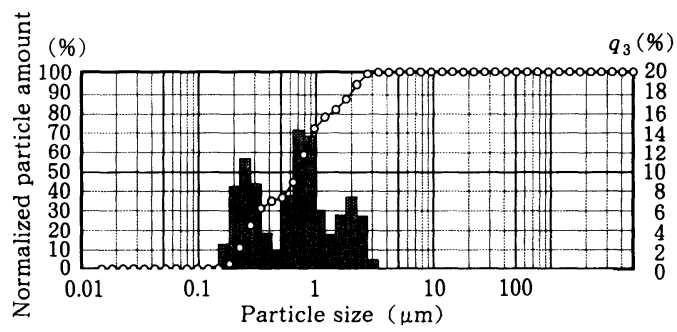

Fig. 10 Particle size distribution of tri-modal polystyrene latex measured by SALD - 7000

であるので，単純に波長の比で考えると測定下限値も 6 割程度に下がることになる。上記の二つの実験結果 によれば，中心径で見た場合の測定下限は 2 分の 1 以 下となっており，波長の比から期待される以上の効果 が現れていることがわかる。この結果は，主には波長 が短くなったことによる散乱パターンの変化と, 検出 系の変更による測定散乱角度範囲の拡大という二つの 変更によるものである。さらに，短波長レーザを採用 したことは，Mie 理論から予測されるとおり，同一 の粒子径に対する散乱強度をより強くするという副次 的効果も生むため, 結果として散乱強度分布測定にお ける S / N 比も向上している。このようなことが総合 的に作用した結果として, 測定下限值を従来の 2 分の 1 以下に引き下げることになったと考える。

測定下限の引き下げには直接影響を与えないため, ここまでは特に触れなかったが，光学系の基本構成が 変化しているため, 光強度分布一粒子径分布変換プロ グラムも，当然のことながらそれにあわせて変更され ている。

\section{3 ラテックス標準球（多峰性分布）}

公称值 $0.3 \mu \mathrm{m}, 0.8 \mu \mathrm{m}, 2.0 \mu \mathrm{m}$ の 3 種のラテッ クス標準球混合物をSALD-7000 で測定した。結果 
を Fig. 10 に示す。多峰性分布が明確に検出されてお り, サブミクロン域において高分解能測定が実現され ていることがわかる。

\section{5. 結 言}

レーザ回折・散乱法を原理とする粒子径分布測定装 置においては, 従来, 赤色レーザ光源が用いられてい たが, より波長の短い青紫色レーザを光源とし，その 性能を検討した。さらに, 光源の変更に加えて, 大口 径の集光レンズを採用することで，前方散乱光測定用
変形同心円センサで捕捉する散乱角範囲を, 約 60 度 まで拡大し，粒子径分布を実際に測定した。その結 果,

1 ) 数 $10 \mathrm{~nm}$ 領域で粒子の識別能力の向上。

2 ) 数 $100 \mathrm{~nm}$ の領域での分解能の向上。 が見られ，微粒子領域におけるレーザ回折・散乱法の 測定能力向上に青紫色レーザの有効であることが確認 できた。また，青紫色レーザの有効性を生かすため, 検出レンズの大口径化も有効である。

\section{Nomenclature}

$D$ : particle diameter

$\alpha$ : size parameter

$$
\underset{(-)}{(\mu \mathrm{m})} \quad \lambda \text { : wave length }
$$

\section{References}

1) Born, M. and E. Wolf : "Principle of optics III", Tokaidaigaku-shuppankai, p. 947 (1975)

2 ) Bohren, G. and D. Huffman : "Absorption and Scatter- ing of Light by Small Particles", John Wiley \& Sons, pp. 82-129 (1983) 